\title{
Periprotetikus distalis femurtörések minimál invazív lemezes rögzítése totál térdprotézis beültetése után
}

\author{
DR. GÁRGYÁN ISTVÁN ${ }^{1}$, DR. CSONKA ÁKOS ${ }^{1}$, DR. BOA KRISTÓF',
}

\author{
DR. KÖRMÖNDI SÁNDOR ${ }^{1}$ DR. TÓTH KÁLMÁN², DR. VARGA ENDRE ${ }^{1}$
}

\section{ÖSSZEFOGLALÁS}

Az utóbbi években a lakosság átlagéletkora, az osteoporosis súlyossága és gyakorisága, valamint a beültetett totál térdprotézisek száma folyamatosan növekszik. Ebből adódóan a periprotetikus törések száma is növekszik és a jövőben egyre nagyobb kihívást jelentenek az ortopéd-traumatológusok számára. A distalis femur a leggyakoribb helye a periprotetikus töréseknek totál térdprotézisek beültetése után. A szerzők 2007-2012 közötti időszakban 9 beteget kezeltek a distalis femur periprotetikus törése miatt. A töréseket a Less Invasive Stabilisation System - Distal Femur (LISS-DF) szögstabil lemezzel rögzítették. Az osteoporosis miatt proximalisan mindig bicorticalis csavarokat használtak, distalisan a lehető legtöbb csavart helyeztek be. A betegek állapotát a Knee Society Score (KSS) és Functional Score (FS) alapján értékelték. Mérték a térd mozgástartományát és a törésátépülés idejét. Az eredményeket a térdprotézis beültetése előtt és után készült KSS és FS értékekhez hasonlították. Az operált 9 eset 0,95\%-os arányt jelent a beültetett protézisek számához viszonyítva. A betegek átlagéletkora 74,3 év volt, a protézis beültetése és a törés között átlagosan 26,8 hónap telt el. A törésátépülés ideje átlagosan 15,3 hét volt. 26 héttel a mútét után a mozgástartomány $0-110^{\circ}$ közötti, míg a KSS/FS érték 58,2/71,6 volt, ami csaknem azonos a sérülés előtti értékekkel. Az eredmények alapján a szerzők a LISS-DF lemezt kiválóan alkalmasnak tartják periprotetikus törések kezelésére, mivel minimál invazív módon behelyezhető és osteoporotikus csontban, kis distalis csontblokk esetén is stabil rögzítést biztosít. A relatív stabilitás elvének megfelelően, a törés rövid idő alatt jó periostealis callussal gyógyul.

\section{Kulcsszavak: $\quad$ Arthroplastica, térd; Belsö rögzítés; Csavarozás; Femurtörés;} Lemezes rögzítés; Minimál invazív technika; Periprotetikus törés; Töréskezelés;

I. Gárgyán, Á. Csonka, K. Boa, S. Körmöndi, K. Tóth, E. Varga: Minimally invasive plate osteosynthesis of distal periprosthetic femoral fractures after total knee replacement

The mean age of the population, the severity and prevalence of osteoporosis, and the number of total knee replacements are equally on a constant rise over the last few years. The consequent rise of periprosthetic fractures are going to present a growing challenge to orthopaedic trauma specialists. The distal femur is the most frequent site of periprosthetic fractures following total knee replacements. The authors treated nine patients with perisprosthetic fracture of the distal femur between 2007 and 2012. The fractures were fixed with Less Invasive Stabilisation System - Distal Femur angular stable plate. Proximal screws were placed bicortically, while as many screws were placed distally as possible, due to the osteoporosis in all cases. Patients were evaluated by using Knee Society Score (KSS) and Functional Score (FS). Range of motion and time of fracture union were measured as well. The results were compared to KSS and FS values measured both before and after the knee replacement. The 9 treated cases represented $0.95 \%$ of all total knee replacements. The mean age was 74.3 , while an average of 26.8 months elapsed between the joint replacement and the fracture. The time of fracture union was 15.3 weeks on the average. The range of motion was $0-110^{\circ}$, while $\mathrm{KSS} / \mathrm{FS}$ values were $58.2 / 71.6$, being about equivalent to the values measured before the injury. Taking the results of this study into account, the authors consider the LISS-DF plate perfectly suitable for the treatment of periprosthetic distal femur fractures, as it can be 
placed in a minimally invasive way, and it provides stable fixation in case of an osteoporotic bone with a small distal block of bone as well. In accordance with the principles of relative stability, the fractures heal with good periosteal callus in a short period.

Keywords: $\quad$ Arthroplasty, replacement, knee-Methods; Bone plates; Bone screws; Femoral fractures - Surgery; Fracure fixation, internal - Methods; Minimally invasive surgical procedures; Periprosthetic fractures - Surgery;

\section{BEVEZETÉS}

Az utóbbi évtizedekben a lakosság átlagéletkora és ezzel egy időben a kialakuló gyulladásos és degeneratív térdízületi elváltozások, valamint az osteoporosis gyakorisága és súlyossága fokozatosan növekszik. A térdízületi arthroplastica az egyik leggyakrabban elvégzett ortopéd sebészeti beavatkozássá vált világszerte, de a 90-es évek eleje óta hazánkban is nagy számban történnek ilyen jellegú mütétek. Az Országos Egészségbiztosítási Pénztár adatai szerint 2013-ban 4800 totál térdprotézis (TTP) beültetés történt Magyarországon (20). A műtétek számának növekedésével sajnos együtt jár a komplikációk számának emelkedése is. Ezek közül az egyik legsúlyosabb szövődmény a femur supracondylaris törése, amelynek gyakoriságát a szakirodalom 0,6-2,5\%-ra becsüli $(1,17,24)$, de a patellán és a proximalis tibia területén is előfordulnak törések $(3,5)$. A fenti adatok alapján hazánkban évente 30-120 esettel számolhatunk. A törés a mindennapi élet során kis erőbehatásra következik be, rendszerint elesést követően. A törés mellett a sérültek általános állapota és társult betegségei is kedvezőtlenül befolyásolhatják a későbbi rehabilitációt, a járóképesség viszszaállítását. Az osteoporotikus csontállomány, a beültetett protézis és a csontcement akadályozhatják a törés repozícióját és megfelelő rögzítését, ezzel akadályozva a törésgyógyulást $(2,3,7)$. A megfelelő kezelés kiválasztása ezért alapvető fontosságú. A törések egy része ugyan kezelhető konzervatív módon is, de ez sok kellemetlenséggel járhat a betegnek, jelentős fájdalom és mozgásbeszűkülés kísérheti (2). A széles körben elterjedt intramedullaris rögzítéssel elért jó eredményekről számos külföldi közlemény mellett egy hazai szerző közleménye is megjelent (23), de a módszer nem minden fajta totál térdprotézis esetén alkalmazható.
A törés feltárása és lemezes rögzítése számos szövődményhez, elhúzódó törésgyógyuláshoz, álízület kialakulásához vezethet (8). A minimál invazív lemezes osteosynthesisek (MIPO) elterjedése a supracondylaris femurtörések kezelésében ugyanakkor segít megőrizni a csont periostealis vérellátását, minimalizálja a lágyrész károsodást, emellett jó klinikai és radiológiai eredményekhez vezet, ezért jól használható a periprotetikus törések ellátásában (19). A térdprotézis beültetés után kialakuló distalis femurtörések MIPO technikával történő megoldásáról szóló közlemény az általunk ismert hazai irodalomban nem szerepel, ezért közleményünkben az irodalom áttekintése mellett, saját eseteink kapcsán szeretnénk bemutatni a mútéttechnikát és az általunk elért eredményeket.

\section{ANYAG ÉS MÓDSZER}

A Szegedi Tudományegyetem Traumatológiai Klinikáján 2007. január és 2012. december között 9 beteget operáltunk periprotetikus supracondylaris femur törés miatt. A törések osztályozását Rorabeck and Taylor (22) (1. ábra) és Kim (14) szerint végeztük (I. táblázat). Minden betegünk törését a megfelelő preoperatív előkészítést követően minimál invazív technikával, a LISS-DF (Less Invasive Stabilisation System-Distal Femur; J\&J DePuy Synthes ${ }^{\circledR}$ ) lemezeket használva stabilizáltuk. A mútétet hanyatt fekvő helyzetben végeztük, az ép végtagot kissé lesüllyesztve, hogy megkönnyítsük a törés oldal irányú kontrollját képerősítő alatt. Az operált oldalon a comb alá, a térdhajlattól kissé proximalisan kiemelést helyeztünk, ezzel megszüntetve a distalis fragmentum hyperextenzióját. A törést emellett hosszanti húzással, illetve indirekt manipulációval reponáltuk. A lemez behelyezése előtt minden esetben képerősítő 
segítségével meggyőződtünk, hogy a végtag hosszát, a rotációt, a valgus-varus dislocatiót és a recurvatiót megszüntettük. Lateralisan a tuberculum Gerdy-től proximal felé $6-8 \mathrm{~cm}$-es metszést ejtve, a rendszer célzóját használva, lágyrész alagúton vezettük proximal felé a lemezt, melynek helyzetét képerősítő alatt kontrolláltuk. Amennyiben a törés és a lemez helyzete megfelelő volt, distalisan behelyeztük a szögstabil csavarokat, lehetőség szerint mind az 5-öt. Kis distalis csontblokk esetén is legalább 4 csavart be tudtunk helyezni. A proximalis regióban legalább három, de az osteoporotikus csontállomány miatt inkább négy bicorticalis szögstabil csavart kellett behelyezni.

A posztoperatív első napon CPM-et

I

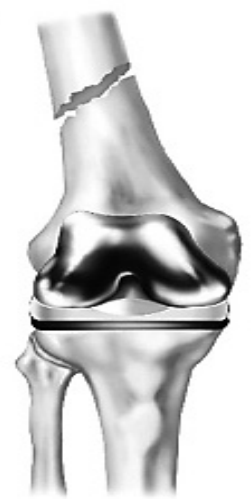

II

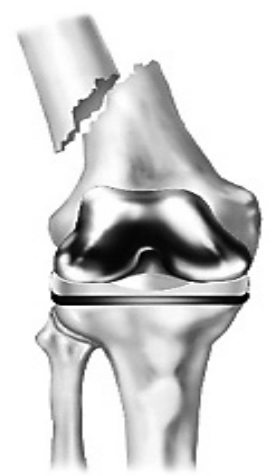

(Continuous Passive Motion) kezdtünk végezni, majd gyógytornász segítségével járókerettel vagy mankóval, a sérült végtagot tehermentesítve, megkezdtük a beteg mobilizálását. A 6. héttől kezdve részleges terhelést engedélyeztünk, amelyet a beteg kontrollja mellett fokozatosan növeltünk.

Minden beteget 12 hónapig rendszeresen radiológiailag kontrolláltunk a protokollnak megfelelő 6-12-16-26-52. héten. Törésgyógyulás után, a 26. héten a betegek állapotát a Knee Society Score (KSS) és Functional Score (FS) alapján értékeltük (12). Mértük a térd mozgástartományát (ROM). Az eredményeket a totál térdprotézis beültetése előtt és az utána készült KSS és FS értékekhez hasonlítottuk.

1. ábra Periprotetikus supracondylaris femur törések osztályozása Rorabeck and Taylor szerint I. Nem diszlokált törés, stabil protézis

II. A törés diszlokáció $\geq 5 \mathrm{~mm}$ vagy az angulatio $\geq 5^{\circ}$, stabil protézis

III. Kilazult vagy instabil protézis, függetlenül a diszlokáció értékétöl

\begin{tabular}{|c|c|c|}
\hline \multicolumn{2}{|c|}{ I. táblázat Periprotetikus supracondylaris femur törések osztályozása Kim szerint } \\
\hline TÖRÉS TíPUSA & MEGHATÁROZÁs & JAVASOLT KEZELÉS \\
\hline IA & $\begin{array}{c}\text { Stabil implantátum } \\
\text { Stabil törés }\end{array}$ & $\begin{array}{c}\text { Nonoperatív kezelés } \\
\text { Gipsz vagy brace, } \\
\text { tehermentesítés }\end{array}$ \\
\hline IB & $\begin{array}{c}\text { Stabil implantátum } \\
\text { Instabil törés }\end{array}$ & $\begin{array}{c}\text { Operatív kezelés: } \\
\text { Lateralis szögstabil lemez } \\
\text { Retrográd velöúrszeg }\end{array}$ \\
\hline II & Kilazult implantátum \\
& Megfelelő csontállomány & Operativ kezelés: \\
\hline III & Kilazult implantátum & Revíziós arthroplastica \\
\hline & Rossz csontállomány & Operatív kezelés/végtagmentés: \\
& & Allograft-protézis kompozit \\
\end{tabular}




\section{EREDMÉNYEK}

A 2007-2012 közötti időszakban a Szegedi Tudományegyetemen 870 betegnél 947 totál térdprotézis beültetés történt. Ugyanezen időszak alatt 9 beteget operáltunk térdprotézis mellett kialakult periprotetikus törés miatt. A beültetett protézisek számához viszonyítva ez 0,95\%-os (9/947) arányt jelent. A 8 nő és 1 férfi beteg átlagéletkora 74,3 év (67-81 év) volt.

Minden beteg egyszerű elesést követően szenvedte el periprotetikus törését, átlagosan 26,8 hónappal a térdprotézis beültetését követően. Az adatokat a II. táblázatban foglaltuk össze. A Kim szerinti beosztásban három beteg törése volt stabil, elmozdulás nélküli, a további hat eset az I/B típusba tartozott, míg a Rorabeck and Taylor szerinti osztályozásban három beteg az I., hat beteg pedig a II. csoportba került. Az I. csoportba tartozó, minimális elmozdulással járó, vagy elmozdulás nélküli töréseket is megoperáltuk, ezzel elősegítve az idős betegek minél gyorsabb mobilizációját, rehabilitációját. $A$ beültetett LISS-DF lemez hossza egy esetben volt csak 5 lyukas, ahogy tapasztalataink nőttek, úgy egyre hoszszabb lemezeket helyeztünk be: két esetben 7 lyukas lemezt, majd a későbbi hat esetben kizárólag 9 lyukas lemezeket. A distalis csontblokkba nyolc betegnél 5 szögstabil csavart tudtunk behelyezni, míg egy esetben a kis csontblokkba 4 csavar került, ezzel megfelelő rögzítést biztosítva a lemez distalis részének. Hét esetben proximalisan a lemezt $4 \mathrm{db}$ bicorticalis szögstabil csavarral rögzítettük a femur diaphysishez, két esetben pedig hárommal. A törésátépülés ideje átlagosan 15,3 hét volt (12-16 hét). Minden törés átépült, elhúzódó csontgyógyulást, álízület kialakulását nem észleltük. A mútét után egy esetben tapasztaltunk korai, felületes infekciót, amely azonban megfelelő kezelést követően gyorsan szanálódott, sebfeltárásra, implantátum eltávolításra emiatt egy esetben sem kényszerültünk. Az utánkövetés ideje alatt implantátumtörést, kiszakadást vagy a törésben redislocatiót nem észleltünk. A LISS-DF eltávolítására egy esetben kényszerültünk, amikor betegünk a törésgyógyulás 15. hetében, újabb elesést követően a lemez proximalis végénél szenvedett el újabb törést (2. $a-c$ ábra). Bár a primer törés radiológiailag már csaknem átépült, a diaphysis törés rögzítésére a retrográd velőűr szegezést választottuk, amely rögzítette a distalis csontblokkot is. A 3. ábrán bemutatott esetben pedig az elégtelen mútéti repozíció és stabilizálás miatt a 3. napon reoperációt végeztünk, amely után jó átépülést sikerült elérni a törésben.

A törésgyógyulás után a 26 . héten minden betegnél megvizsgáltuk a térd teljes mozgástartományát, mely $0-110^{\circ}$ közötti volt. A betegek állapotát felmérő KSS/FS értékeket a totál térdprotézis beültetése előtt és az utána készült KSS/FS értékekhez hasonlítottuk (4. ábra). A protézis beültetés utáni 63,2/80 KSS/FS értékekhez viszonyítva a törésgyógyulás után azt megközelítő 58,2/71,6 értékeket kaptunk. A további kontrollokon ezen értékek javulását már nem tapasztaltuk.

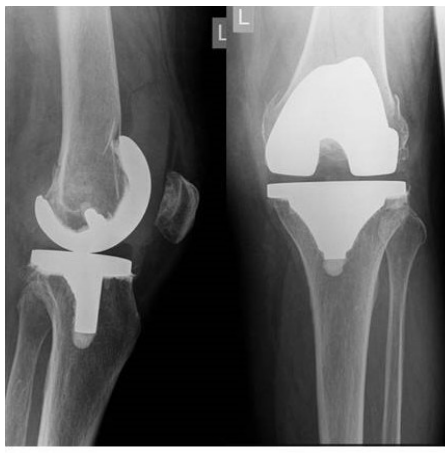

a

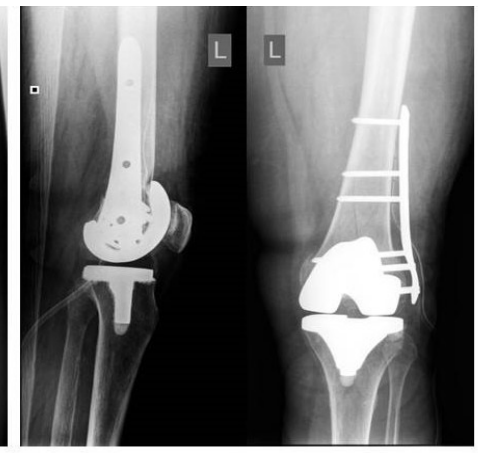

b

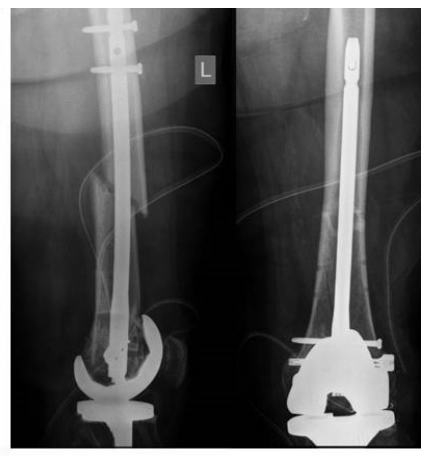

C

2. ábra a) A 79 éves nöbeteg 32 hónappal a TTP beültetés után szenvedte el periprotetikus törését. Jelentős anterior femoral notching

b) A törést túl rövid, 5 lyukas LISS-DF lemez rögzíti

c) Periimplantatikus törés a lemez proximalis végénél 15 héttel a mütét után, amelyet retrográd velöür szeggel rögzítettünk 


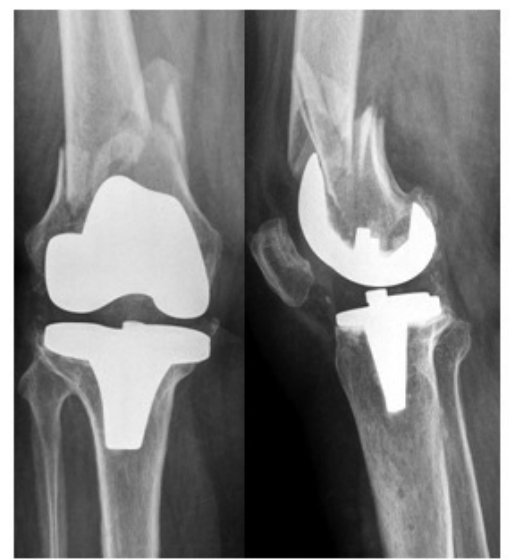

a

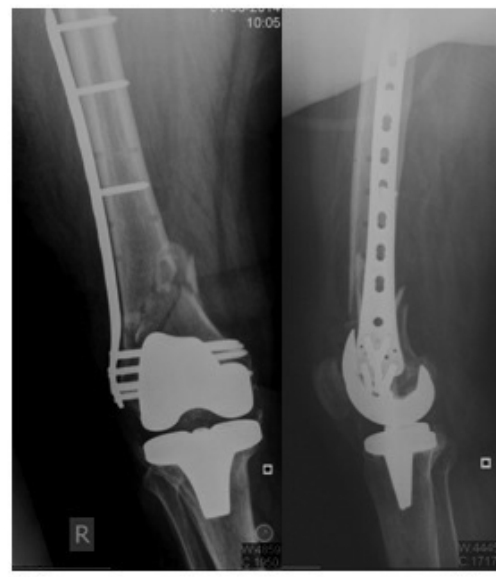

C

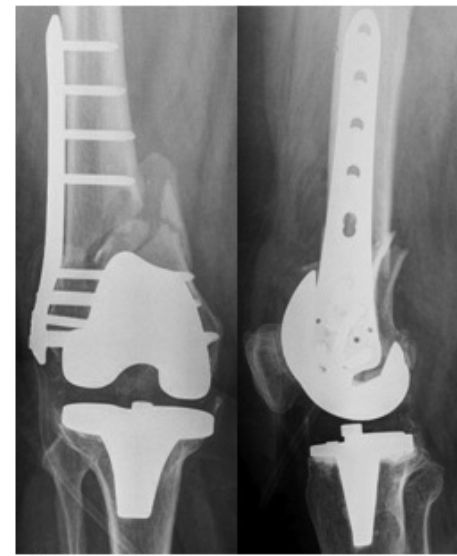

$\mathrm{b}$

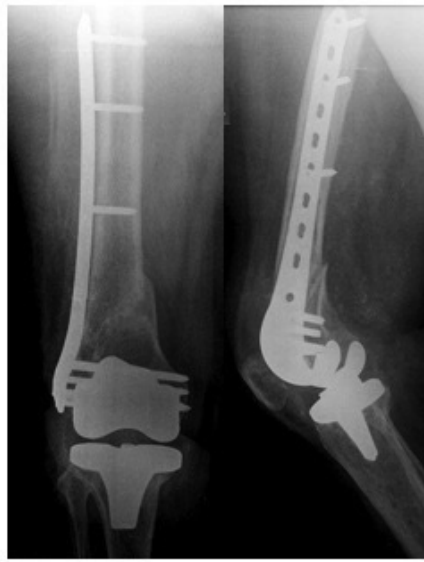

d

3. ábra a) 67 éves nöbeteg mütét elötti kétirányú röntgenfelvételei

b) Az első mütét utáni röntgenfelvételek: jelentős diszlokáció mellett túl rövid lemez rögzíti a törést c) A három nap múlva elvégzett reoperáció utáni kontrollfelvételek d) Az átépült törés

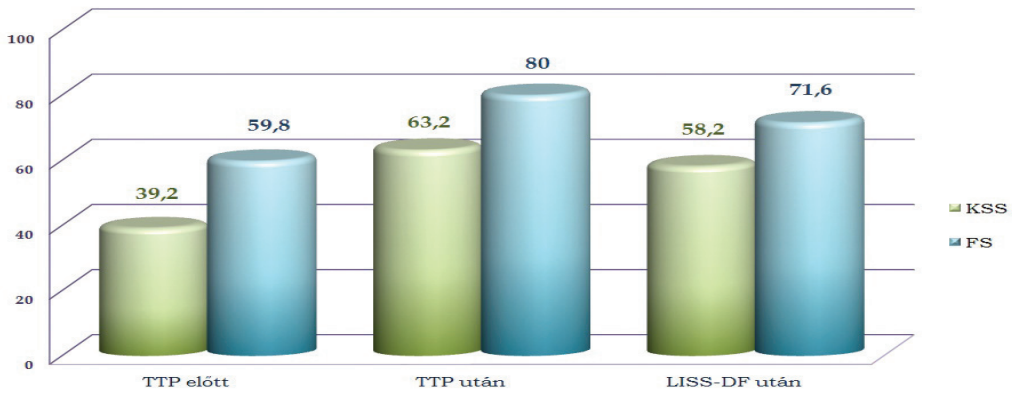

4. ábra Knee Society Score + Functional Score 


\begin{tabular}{|c|c|c|c|}
\hline \multicolumn{4}{|l|}{ II. Összefoglaló táblázat } \\
\hline Kim klasszifikáció & \multicolumn{2}{|c|}{$n=31 A$} & $n=61 B$ \\
\hline Rorabeck and Taylor & \multicolumn{2}{|c|}{$n=3 \mathrm{I}}$. & $\mathrm{n}=6 \mathrm{II}$. \\
\hline LISS hossza & 5 lyukú $n=1$ & 7 lyukú $n=2$ & 9 lyukú $n=6$ \\
\hline Distalis csavarok száma & \multicolumn{3}{|c|}{ (4) 5} \\
\hline Proximalis csavarok száma & \multicolumn{3}{|c|}{ (3)4 } \\
\hline Átépülés ideje (hét) & \multicolumn{3}{|c|}{15,3} \\
\hline Álízület & \multicolumn{3}{|c|}{0} \\
\hline Rediszlokáció & \multicolumn{3}{|c|}{0} \\
\hline Implantátumlazulás & \multicolumn{3}{|c|}{0} \\
\hline Implantátumtörés & \multicolumn{3}{|c|}{0} \\
\hline Infekció & \multicolumn{3}{|c|}{1} \\
\hline Csontpótlás & \multicolumn{3}{|c|}{0} \\
\hline KSS/FS & \multicolumn{3}{|c|}{$58,2 / 71,6$} \\
\hline ROM & \multicolumn{3}{|c|}{$0-110^{\circ}$} \\
\hline
\end{tabular}

\section{MEGBESZÉLÉS}

A beültetett térdprotézis mellett kialakuló törés rendszerint kis erőbehatásra, megbotlás, elesés után következik be a rendszerint idős betegeken. A törés létrejöttében kétségtelenül az osteoporosis nagy szerepet játszik, de számos egyéb tényező is hozzájárulhat kialakulásához: tartós kortikoszteroid használat, rheumatoid arthritis, Parkinson-kór, myasthenia gravis $(2,5)$. Navigációs arthroplastica után is létrejöhet a nyársak helyén (18). Számos közlemény számolt be az anterior femoral notching jelentőségéről (2. a ábra), amikor a femur elülső felszínén túlzott reszekció történik $(4,21)$. Irodalmi adatok szerint $3 \mathrm{~mm}$ elülső notch 30\%-kal csökkenti a csont torziós ellenállását (4).

A töréskezeléseket alapvetően két csoportra oszthatjuk: non-operatív és operatív csoportra. Az extenziós kezelést manapság már alig alkalmazzuk a jól ismert szövődmények miatt. A Rorabeck l-es csoportba tartozó törések esetén brace vagy gipsz felhelyezése történhet, majd szoros radiológiai kontroll mellett 4-6 hét után a térdízület mozgatása megkezdődhet. Fontos azonban megjegyezni, hogy non-operatív kezelés mellett magas a diszlokációk-rediszlokációk aránya, emellett az álízület kialakulásának veszélye is nagyobb (5,
6). Az operatív technikák közül ma már a feltárásos repozíció és a törés konvencionális lemezzel való rögzítése alig jön szóba az excesszív lágyrész károsítás, a fokozott infekcióveszély, illetve lemeztörés miatt, amelyről hazai szerzők is beszámoltak (11). Az egyik legelterjedtebben használt operatív technika manapság a reteszelt retrográd velőúrszegezés, amelyről a hazai irodalomban egy közlemény jelent meg (23). A módszer hátránya, hogy bizonyos esetekben, például kis distalis csontblokk esetén nem ad megfelelő stabilitást, emellett bizonyos TTP típusoknál nem alkalmazható. A minimál invazív módon behelyezhető szeggel ugyanakkor jó törésátépülés érhető el. Az utóbbi években egyre több közlemény jelent meg a minimál invazív lemezes osteosynthesisekről (13), az osteoporotikus csontokban kiváló rögzítést biztosító szögstabil csavarokról és anatómiai lemezrendszerekről. Az általunk is használt LISSDF rendszerrel Kregor és munkatársai 38-ból 36 esetben értek el szövődménymentes csontos átépülést supracondylaris femurtörések kezelésében (16). Más közlemények az infekciók számának csökkenéséről, gyors törésátépülésről és alacsony komplikációs rátáról számoltak be a konvencionális technikákhoz képest $(16,25)$, míg más szerzők minden esetben jó átépülést értek el megfelelő térdfunkció mellett (19). 
Klinikánkon is kedvező tapasztalatokat szereztünk ezzel a módszerrel a supracondylaris törések kezelésében, így elkezdtük alkalmazni a periprotetikus törések esetén is. Vizsgálatunk időtartama alatt 45 esetben alkalmaztuk a LISS-DF lemezt, ebből 9 eset volt periprotetikus törés $(20 \%, 9 / 45)$. A módszer lényege, hogy a törést indirekt módon reponáljuk, kis metszéseket ejtve, a lágyrészeket és a csont vérellátását megkímélve csúsztatjuk be a lemezt. Nem törekszünk anatómiai repozícióra, a törési zónát áthidaljuk, így a relatív stabilitás elvének megfelelően a törésben mikromozgások révén callus képződés indul meg. A LISS-DF lemez lehetővé teszi, hogy a distalis blokkba helyezett 4-5 szögstabil csavarral erős rögzítést biztosítsunk a csontgyógyulás idejére.

Koreai szerzők közleményükben 14 esetről számolnak be (10), amikor TTP beültetést követő periprotetikus törés LISS-DF lemezzel való rögzítését követően a ROM, KSS/FS értékek a törés előtti értékekkel szinte azonosak voltak: 1080-os mozgástartomány, 78,9/77,1 KSS/FS értékek, míg más szerzők tanulmányában az elért átlagos ROM $102^{\circ}$ volt 23 eset kapcsán
(15). Az általunk végzett vizsgálatban is hasonló eredmények születtek, bár betegeink mútét utáni KSS/FS értékei alacsonyabbak $(58,2 / 71,6)$ voltak, de a törés előtti KSS/FS értékeket $(63,2 / 80)$ csaknem sikerült elérni. Minden betegünk törése szövődménymentesen átépült, átlagosan 15,3 hét (12-16 hét) között, csontpótlásra egy esetben sem kényszerültünk.

Mivel a TTP beültetés utáni periprotetikus törések rendszerint osteoporosis miatt alakulnak ki, fontosnak tartjuk a betegeknél a nemzetközi ajánlásoknak megfelelően (9) már a posztoperatív időszakban a kalcium és D-vitamin raktárak feltöltését, majd a későbbiekben csontsűrűség vizsgálat elvégzését és osteoporosis ambulanciára történő irányítását.

Tapasztalataink és a szakirodalom viszonylag kis esetszámú közleményei alapján a LISS-DF lemezzel végzett periprotetikus törésrögzítés jó klinikai eredményekhez vezet, de további, nagyobb beteganyagon végzett vizsgálatok szükségesek az eredmények pontosabb megítéléséhez. Az értékeléskor figyelembe kell majd vennünk más gyártók hasonló termékeivel elért eredményeket is. 


\section{IRODALOM}

1. Aaron R. K., Scott R.: Supracondylar fracture of the femur after total knee arthroplasty. Clin. Orthop. Relat. Res. 1987. (219): 136-139.

2. Chen F., Mont M. A., Bachner R. S.: Management of ipsilateral supracondylar femur fractures following total knee arthroplasty. J. Arthroplasty. 1994. 9. (5): 521-526.

3. Cordeiro E. N., Costa R. C., Carazzato J. G., Silva Jdos S.: Periprosthetic fractures in patients with total knee arthroplasties. Clin. Orthop. Relat. Res. 1990. (252): 182-189.

4. Culp R. W., Schmidt R. G., Hanks G., Mak A., Esterhai J. L. Jr., Heppenstall R. B.: Supracondylar fracture of the femur following prosthetic knee arthroplasty. Clin. Orthop. Relat. Res. 1987. (222): 212-222.

5. Dennis D. A.: Periprosthetic fractures following total knee arthroplasty. J. Bone Joint Surg. Am. 2001. 83: 120-130.

6. DiGioia A. M. 3rd, Rubash H. E.: Periprosthetic fractures of the femur after total knee arthroplasty. A literature review and treatment algorithm. Clin. Orthop. Relat. Res. 1991. (271): 135-142.

7. Engh G. A., Ammeen D. J.: Periprosthetic fractures adjacent to total knee implants: treatment and clinical results. Instr. Course Lect. 1998. 47: 437-448.

8. Figgie M. P., Goldberg V. M., Figgie H. E. 3rd, Sobel M.: The results of treatment of supracondylar fracture above total knee arthroplasty. J. Arthroplasty. 1990. 5: 267-276.

9. Fragility fracture network (FFN). http://fragilityfracturenetwork.org/

10. Ha C-W., Shon O. J., Lim S. W., Park K. H.: Minimally invasive plate osteosynthesis for periprosthetic distal femoral fractures after total knee arthroplasty. Knee Surgery \& Related Research. 2014. 26. (1): 27-32.

11. Holnapy G., Illyés Á., Böröcz l.: Egy térdprotézis-beültetés tanulságai. Magyar Traumatológia Ortopédia Kézsebészet Plasztikai Sebészet, 2005. 48. (3): 269-277.

12. Insall J. N., Dorr L. D., Scott R. D., Scott W. N.: Rationale of the Knee Society clinical rating system. Clin. Orthop. Relat. Res. 1989. (248): 13-14.

13. Kádas I., Magyari Z., Udvardy Cs., Vecsey G.: A lemezes osteosynthesisek reneszánsza? Mi az a MIPO? Magyar Traumatológia Ortopédia Kézsebészet Plasztikai Sebészet, 2000. 43. (3): 161-169.

14. Kim K. I., Egol K. A., Hozack W. J., Parvizi J.: Periprosthetic fractures after total knee arthroplasties. Clin. Orthop. Relat. Res. 2006. (446): 167-175.

15. Kolb W., Guhlmann H., Windisch C., Marx F., Koller H., Kolb K.: Fixation of periprosthetic femur fractures above total knee arthroplasty with the less invasive stabilization system: a midterm follow-up study. J. Trauma. 2010. 69: 670-676.

16. Kregor P. J., Hughes J. L., Cole P. A.: Fixation of distal femoral fractures above total knee arthroplasty utilizing the Less Invasive Stabilization System (L.I.S.S.). Injury. 2001. 32. (Suppl. 3): SC64-75.

17. Lachiewicz P. F.: Periprosthetic fracture between a constrained total knee arthroplasty and a long-stem total hip arthroplasty: treatment with a novel device. J. Arthroplasty. 2007. 22: 449-452.

18. Li C. H., Chen T. H., Su Y. P., Shao P. C., Lee K. S., Chen W. M.: Periprosthetic femoral supracondylar fracture after total knee arthroplasty with navigation system. J. Arthroplasty. 2008. 23: 304-307.

19. Nayak R. M., Koichade M. R., Umre A. N., Ingle M. V.: Minimally invasive plate osteosynthesis using a locking compression plate for distal femoral fractures. J. Orthop. Surg. (Hong Kong). 2011. 19: 185-190.

20. OEP-Statisztikai Évkönyv, 2013. 124.

21. Ritter M. A., Faris P. M., Keating E. M.: Anterior femoral notching and ipsilateral supracondylar femur fracture in total knee arthroplasty. J. Arthroplasty. 1988. 3: 185-187.

22. Rorabeck C. H., Taylor J. W.: Classification of periprosthetic fractures complicating total knee arthroplasty. Orthop. Clin. North Am. 1999. 30: 209-214.

23. Than P., Börzsei L., Pomeroy D.: Térdizzuleti totál endoprotézis beültetést követö supracondylaris femur törés megoldása reteszelt retrográd intramedullaris fixációval. Magyar Traumatológia Ortopédia Kézsebészet Plasztikai Sebészet, 1999. 42. (4): 324-330.

24. Wick M., Muller E. J., Muhr G.: Supracondylar femoral fractures in knee endoprostheses: stabilizing with retrograde interlocking nail. Unfallchirurg. 2001. 104: 410-413.

25. Zlowodzki M., Williamson S., Cole P. A., Zardiackas L. D., Kregor P. J.: Biomechanical evaluation of the less invasive stabilization system, angled blade plate, and retrograde intramedullary nail for the internal fixation of distal femur fractures. J. Orthop. Trauma. 2004. 18: 494-502.

\section{Dr. Gárgyán István}

SZTE Szent-Györgyi Albert Klinikai Központ Traumatológiai Klinika

6725 Szeged, Semmelweis u. 6 . 